Print ISSN: 2288-4637 / Online ISSN 2288-4645

doi:10.13106/jafeb.2018.vol5.no2.95

\title{
Narcissism and Social Media Addiction in Workplace
}

\author{
Youngkeun Choi $^{1}$
}

Received: April 12, 2018. Revised: April 23, 2018. Accepted: May 15, 2018.

\begin{abstract}
The purpose of this study is to investigate the impact of narcissism on employees' social media addiction and how it influences their job satisfaction and organizational commitment. And this study explores if perceived organizational support can moderate the relationship between narcissism and social media addiction. For this, this study collected data from 285 employees in Korean companies through a survey method and uses SPSS 18.0 for hierarchical regression analysis in the hypothesis test. First, organizational politics increases mood modification, withdrawal and tolerance among the sub-factors of social media addiction. Second, each phenomena of social media service addiction such as salience, withdrawal and tolerance decrease each relevant factors of job satisfaction and organizational commitment. Third, withdrawal and tolerance among the sub-factors of social media addiction play the mediating roles between narcissism and each relevant factors of job satisfaction/organizational commitment. Finally, perceived organizational support decrease the effect of narcissism on mood modification, withdrawal and tolerance among the sub-factors of social media addiction. This study provides some of managerial implications to corporate executives who try to manage organizational attitudes.
\end{abstract}

Keywords: Narcissism, Social Media Addiction, Perceived Organizational Support.

JEL Classification Code: C12, C83, M12, M14.

\section{Introduction}

Recently, social media has become increasingly popular across the world (Kuss \& Griffiths, 2011). People enjoy social media in many various types of social activity including playing games, socializing, passing time, communicating, and posting pictures (Allen, Ryan, Gray, Mclnerney, \& Waters, 2014; Ryan, Chester, Reece, \& Xenos, 2014). Although it has been a normal activity, researchers have concerned about the potential addictive use of social media (Andreassen, 2015; Griffiths, Kuss, \& Demetrovics, 2014).

General addiction model have explained such excessive and compulsive use (Griffiths, 2005). Scholars have suggested cyber-sexual addiction, social media addiction, net compulsions (e.g., stock trading, gambling, shopping), information overload, and computer addiction (e.g., games, programming) (Young, 1999). Therefore, addictive social media use is defined as being overly concerned about social media, driven by an uncontrollable motivation to log on to or use social media, and devoting so much time and effort to social media that it impairs other important life areas (Andreassen \& Pallesen, 2014).

1 Associate Professor, Division of Business Administration, College of Business, Sangmyung University, Seoul, Korea.

E-mail: penking1@smu.ac.kr
As the social media enter the workplace, more needs of to be learned about its effects on the organizational behaviors of employees. However, most of the previous studies have focused on individual behaviors when examining this excessive consumption of new media (Echeburua \& de Corral, 2010; Kuss \& Griffiths, 2011), while research about social media addiction in the context of workplace is rare. Recently, employees use and commit social media excessively rather than work hard, which makes a matter of great concern in the workplaces. Thus, social media addiction should be viewed as one of the serious organizational problems arising in today's workplace. Therefore, the present study will examine the antecedent and consequences of social media addiction in the context of workplace. And it will explore the mediating effects of social media addiction and find out the factors which can manage social media addiction in the workplace.

\section{Literature Review and Hypothesis Development}

\subsection{Antecedents}

A lot of researchers have suggested that personality influences addictive use of social media (e.g., Andreassen et al., 2012, 2013; Hong, Huang, Lin, \& Chiu, 2014; Wilson, 
Fornasier, \& White, 2010). Some recent research have argued that the popularity of social media are an increase in the levels of narcissism in today's society (Mehdizadeh, 2010; Buffardi \& Campbell, 2008). Especially, social media involve the features of communication that differ from offline communication and that might suit narcissistic tendencies (Valkenburg \& Peter, 2011). First, social media provide easy access to a large number of other individuals. Users have the opportunity to send self-related information to a large audience and to receive feedback about oneself and information about others. Second, users can select the information they reveal about themselves. They can use pictures and words to communicate success and superiority. Third, the asynchronicity of communication on social media gives users the opportunity to craft their self-presentations meticulously.

Buffardi and Campbell (2008) showed that users' selfreported grandiose narcissism was significantly related to the quantity of their social interactions (a composite measure of number of friends and number of wall posts) but not to the quantity of information listed in the "about self" section. Furthermore, they rated the extent of self-promoting content (mainly self-promotion in pictures and quotes) on the participants' Facebook pages and correlated these ratings with self-reported grandiose narcissism. Several Facebook content indicators such as self-promoting quotes yielded a positive relationship with self-reported narcissism, whereas others (e.g., self-promoting pictures) did not. These results show that narcissists appear to be particularly attracted to activities that reinforce their sense of selfimportance and provide the means to present themselves favorably to others. They further strive for a large audience by gathering a large number of Facebook friends and craft frequent status updates that reflect their grandiose selfimage.

This seems to be meaningful as social media use allows people to show their ambitions and successes to a potentially large audience, and to obtain highly visible rewards and recognition through "likes" and positive comments from other social media users. Recent studies appear to refer to narcissism as a relatively broad behavioral trait domain, expressed by, among others, selfcentered grandiosity, arrogance, manipulativeness, and similar features (Alarcón \& Sarabia, 2012). Diagnostic and Statistical Manual of Mental Disorders formally recognize narcissistic personality disorder which is a pathological form of narcissism in terms of high levels of self-importance, fantasies of unlimited success, feeling special and unique, lack of empathy, envy, and arrogance (American Psychiatric Association, 2013). However, more moderate and nonclinical levels of narcissistic traits have sometimes been regarded as healthy by providing an outlet for self- confidence and self-assertion (Cambell, Reeder, Sedikides, \& Elliot, 2000; Muller, 2014). Although the definition of social media addiction is inconsistent, social media may serve as a gratifying medium for people with high level of narcissistic traits particularly. When they repeat this iterative patterns of showing their ambitions and successes and obtaining highly visible rewards and recognition in social media world, the level of their psychological dependency on social media increases. Accordingly, the following hypothesis is established.

$<$ Hypothesis 1> Narcissism will be positively associated with social media addiction.

\subsection{Consequences}

Most of researches concerning social media addiction have argued that it made many kinds of negative influence on users. Social network service usage can lead to a variety of negative consequences that imply a potential decrease in involvement in real-life communities (Nyland, Marvez, \& Beck, 2007) and worse academic performance (Kirschner \& Karpinski, 2010), as well as relationship problems (Tokunaga, 2011) in the various context. For example, the results of 184 Internet users' online survey indicated that people who use SNS more in terms of time spent on usage are less involved with their real life communities (Nyland, Marvez, \& Beck, 2007). According to the recent study (Kirschner \& Karpinski, 2010), which assessed relationships between Facebook usage and academic performance in a sample of 219 university students, Facebook users had lower Grade Point Averages and spent less time for studying than students who did not use Facebook. $26 \%$ of students recognized an impact of their SNS usage on their lives, three-quarters $(74 \%)$ claimed that it had a negative impact, namely procrastination, distraction, and poor timemanagement. A potential explanation for this may be that students who used the Internet to study may have been distracted by the simultaneous engagement in SNS as this multitasking is detrimental to academic achievements (Kirschner \& Karpinski, 2010). The usage of Facebook also may produce negative consequences for romantic relationships in some circumstances. The disclosure of rich private information on one's Facebook page including status updates, comments, pictures, and new friends, can result in jealous cyberstalking (Phillips, 2009), including interpersonal electronic surveillance (Tokunaga, 2011) by one's partner. This was reported to lead to jealousy (Muise, Christofides, \& Desmarais, 2009; Persch, 2007) and, in the most extreme cases, divorce and associated legal actions (Luscombe, 2009).

However, few studies of social media addiction have been interested in the context of workplace. Similar to the above contexts, although social media use provides users psychological rewards, they are likely to engage in the 
activity more and more, which eventually leads to many problems in workplace. If employees spend a lot of time using and committing social media excessively rather than work hard, it will make a matter of negative consequences in the workplace. I suggest job satisfaction and organizational commitment as two kinds of the organizational attitudes of employees which are negatively influenced by social media addiction.

First, job satisfaction conveys useful information about an individual's economic, social, and personal life as it is a major determinant of labor market mobility (Freeman, 1978; Park et al., 2016), job performance (Mount et al., 2006), and personal well-being (Rode, 2004). Similar to other context, if employees use social media more in terms of time spent on usage, they are less interested in their real life in workplace, which their job satisfaction decreases. Second, relevant studies defined organizational commitment in terms of nature of relationship (Grusky, 1996; Chun et al., 2016; Kwon \& Yang, 2015), loyalty to employer (Kim et al. 1996), integration of individual and organizational goals (Hall, 1970), identification with or attachment to the organization (Romsek, 1989), readiness to exert considerable effort on behalf of the organization, and strong desire to remain a member of the organization (Balaji, 1985). When employees are more addictive in social media use, they are more likely not only to ignore their real life in workplace, which their organizational commitment decreases. Accordingly, the following hypothesis is established.

$<$ Hypothesis 2> Social media addiction will be negatively associated with job satisfaction.

$<$ Hypothesis $3>$ Social media addiction will be negatively associated with organizational commitment.

\subsection{Mediating effect}

Recently, narcissism in organization management has become a growing area. Although the growth of research on narcissism has not yet been integrated with a model of organizational management, narcissism seems to have some significant implications for organizational management. Organizational management tries to align employees' efforts in pursuit of organizational goals through planning, assessing performance, providing feedback, and adapting accordingly (Aguinis, 2013; Aguinis \& Poerce, 2008; DeNisi \& Pritchard, 2006). Organizational management leads to higher employee performance if it strengthen the linkages between employees' action and their need satisfaction (DeNisi \& Pritchard, 2006).

Research focused on the antecedents of job satisfaction has shifted appreciably since the mid-eighties from a focus on role perceptions and organizational variables to how personality traits might influence these feelings. Narcissistic employees with more ego threats from their jobs are less satisfied with their jobs. Because of the exploitiveness/ entitlement and superiority/arrogance components of their narcissistic personality (Wallace \& Baumeister, 2002; Judge et al., 2006; Maynard et al., 2015).

Narcissism has been linked to workplace deviance and contextual performance (Judge, LePine, \& Rich, 2006, O'Boyle, Forsyth, Banks, \& McDanel, 2012). This issue become important due to the growth in narcissism, which researchers consider an epidemic (Twenge \& Campbell, 2009). Due to their selfish nature, sense of entitlement, exploitive personalities, sense of superiority, and social callousness, they seem quite likely to engage in deviant organizational and deviant interpersonal dimensions of salesperson deviant behaviors described by Jelinek and Ahearne (2006). Therefore, those with the higher level of narcissism are less committed to their organizations. As results, they shows more counterproductive work attitudes.

I explore the possibility of mediating effect of SNS addiction between the narcissism and the work attitudes of employees. The employees with high level of narcissistic traits in workplaces can use social media to show their ambitions and successes and obtain highly visible rewards and recognition in social media world. However, although they may have self-confidence and self-assertion (Cambell, Reeder, Sedikides, \& Elliot, 2000; Muller, 2014), they cannot help repeating this iterative patterns through using social media addictively, so that their job satisfaction and organizational commitment will decrease. Accordingly, the following hypothesis is established.

\section{$<$ Hypothesis $4>$ Social media addiction will mediate the relationship between narcissism and job satisfaction. \\ $<$ Hypothesis 5> Social media addiction will mediate the relationship between narcissism and organizational commitment.}

\subsection{Moderator}

Organizational support theory (OST) suggests that employees form expectancies of support based on the degree to which the organization both values employees' contributions and demonstrates concern for their well-being (Eisenberger, Huntington, Hutchinson, \& Sowa, 1986). Based on OST, I expect perceived organizational support (POS) to buffer the positive relationship between narcissism and work attitudes. A supportive work environment signals that the employee is a valued member of the organization, which can lead to resource accumulation through its positive impact on one's sense of self-worth and its satisfaction of 
the fundamental human need for belongingness (Rhoades \& Eisenberger, 2002). Self-esteem and feeling a sense of belonging are both important socio-emotional resources and so events or experiences that replenish or increase them can potentially counteract the socio-emotional resources that narcissism demands.

Narcissism is referred to as a relatively broad behavioral trait domain, expressed by, among others, self-centered grandiosity, arrogance, manipulativeness, and similar features (Alarcón \& Sarabia, 2012). These traits provide an outlet for self-confidence and self-assertion (Cambell, Reeder, Sedikides, \& Elliot, 2000; Muller, 2014). Because social media use allows people to show their ambitions and successes to a potentially large audience, and to obtain highly visible rewards and recognition and positive comments from other social media users, the level of their psychological dependency on social media increases. However, more employees perceive that the organization values employees' contributions and demonstrates concern for their well-being, less they need to be addictive in social media. Accordingly, the following hypothesis is established.

$<$ Hypothesis 6> POS will decrease the positive relationship between narcissism and social media addiction.

\section{Methodology}

\subsection{Data collection and sample}

The objective of the study is to identify behavioral factors related to social media addiction by an empirical test. The factors of organizational behaviors can be identified by measuring organization's members' perceptions in the workplace situations. I adopted an online survey method using a convenience sampling for data collection as it is very useful in collecting data from a large number of individuals in a relatively short period of time and at better cost.

To test our hypotheses of this study, a self-completion questionnaire was administered to business office workers (20-59 years old) in South Korea. All participants received an email requesting for this online survey with an accompanying email that explains the purpose of the survey, emphasized a voluntary participation, and guaranteed confidently. Participants were asked to fill out the questionnaire.

The survey questionnaire consisted of three parts. In the first part of survey questionnaire, participants were instructed to read the purpose of the survey. The second part of the questionnaire included the items measuring the respondent's narcissism, social media addiction, job satisfaction, organizational commitment. The third part of the study consisted of basic information about firm profiles and respondents' characteristics, using nominal scales (e.g., demographic variables, the industry of their companies, the number of employee, tenure, etc.)

Finally, I collected 285 complete responses from the online survey. The characteristics of respondents is reported in Table 1 (e.g., age, gender, the industry of their companies, the number of employees in their companies, tenure, the level of their education, the marital status).

Table 1. Sample Profile

\begin{tabular}{|c|c|c|}
\hline Variables & Items & Percentages \\
\hline \multirow{4}{*}{ Age } & 20 's & 24.6 \\
\hline & 30 's & 27.4 \\
\hline & 40 's & 22.4 \\
\hline & 50 's & 25.6 \\
\hline \multirow{2}{*}{ Gender } & Male & 46.3 \\
\hline & Female & 53.7 \\
\hline \multirow{6}{*}{$\begin{array}{l}\text { Industry of } \\
\text { their company }\end{array}$} & Manufacturing & 28.8 \\
\hline & Construction & 10.2 \\
\hline & Service & 32.2 \\
\hline & Public agency & 5.6 \\
\hline & Wholesale/retail & 8.1 \\
\hline & Etc. & 15.1 \\
\hline \multirow{5}{*}{$\begin{array}{c}\text { Number of } \\
\text { Employee } \\
\text { in their company }\end{array}$} & Less than 10 & 20.7 \\
\hline & $11 \sim 50$ & 29.8 \\
\hline & $51 \sim 300$ & 29.5 \\
\hline & $301 \sim 1000$ & 7.1 \\
\hline & More than 1001 & 12.9 \\
\hline \multirow{5}{*}{ Tenure } & Less than 5 years & 53.3 \\
\hline & $6 \sim 9$ years & 23.5 \\
\hline & 10 14 years & 12.3 \\
\hline & $15 \sim 19$ years & 4.2 \\
\hline & More than 20 years & 6.7 \\
\hline \multirow{5}{*}{$\begin{array}{l}\text { Level of } \\
\text { their education }\end{array}$} & Middle school & 0.7 \\
\hline & High school & 15.8 \\
\hline & Community college & 20.8 \\
\hline & Undergraduate school & 52.9 \\
\hline & Graduate school & 9.8 \\
\hline \multirow{6}{*}{ Position } & Staff & 44.6 \\
\hline & Assistant manager & 18.2 \\
\hline & Manager & 15.4 \\
\hline & Senior manager & 13.3 \\
\hline & Director & 6.3 \\
\hline & Etc. & 2.1 \\
\hline \multirow{2}{*}{ Marital Status } & Married & 54.7 \\
\hline & Single & 45.3 \\
\hline
\end{tabular}




\subsection{Measurement}

Table 2 show the measurements of variables in the present study.

Table 2. The measurements of variables

\begin{tabular}{|c|c|c|}
\hline Variables & Sub-factors & References \\
\hline Narcissism & - & Ames et al.(2006) \\
\hline \multirow{6}{*}{ Social media addiction } & Salience & \multirow{5}{*}{ Andreassen et al.(2017) } \\
\hline & Conflict & \\
\hline & Mood modification & \\
\hline & Withdrawal & \\
\hline & Tolerance & \\
\hline & relapse & \\
\hline \multirow{5}{*}{ Job satisfaction } & Work & \multirow{5}{*}{ Smith et al.(1969) } \\
\hline & Pay & \\
\hline & Promotion & \\
\hline & Colleague & \\
\hline & Supervision & \\
\hline \multirow{3}{*}{ Organizational commitment } & Affective commitment & \multirow{3}{*}{ Allen \& Meyer(1990) } \\
\hline & Continuance commitment & \\
\hline & Normative commitment & \\
\hline Perceived organizational support & - & Wayne et al.(1987) \\
\hline
\end{tabular}

Table 3. Variables' correlation coefficient and other statistics

\begin{tabular}{|c|c|c|c|c|c|c|c|c|c|c|c|c|c|c|c|}
\hline & 1 & 2 & 3 & 4 & 5 & 6 & 7 & 8 & 9 & 10 & 11 & 12 & 13 & 14 & 15 \\
\hline Narcissism & 1 & & & & & & & & & & & & & & \\
\hline Salience & -.062 & 1 & & & & & & & & & & & & & \\
\hline Conflict & .021 & .000 & 1 & & & & & & & & & & & & \\
\hline $\begin{array}{c}\text { Mood } \\
\text { modification }\end{array}$ & $.012 * *$ & .000 & .000 & 1 & & & & & & & & & & & \\
\hline Withdrawal & $.033 * *$ & .000 & .000 & .000 & 1 & & & & & & & & & & \\
\hline Tolerance & $.102 * *$ & .000 & .000 & .000 & .000 & 1 & & & & & & & & & \\
\hline Relapse & .019 & .081 & .042 & .062 & -.019 & .029 & 1 & & & & & & & & \\
\hline Work & $-.123 * *$ & .012 & -.022 & -.306 & -.022 & $-.018 * *$ & -.043 & 1 & & & & & & & \\
\hline Pay & .022 & .032 & .021 & .015 & -.020 & .029 & .062 & -.011 & 1 & & & & & & \\
\hline Promotion & -.101 & .024 & -.032 & .033 & -.001 & .032 & -.011 & -.032 & .000 & 1 & & & & & \\
\hline Colleague & $-.121 *$ & $-.021 *$ & -.101 & -.036 & $-.023 * *$ & -.101 & -.114 & .028 & .018 & .005 & 1 & & & & \\
\hline Supervision & $-.021 *$ & .022 & -.121 & -.079 & $-.058 * *$ & .024 & -121 & -.019 & .000 & .000 & -.052 & 1 & & & \\
\hline Affective & $-.031 * *$ & .032 & -.082 & -.022 & -.039 & $-.044 *$ & -.113 & $.221 * *$ & .043 & -.062 & .130 & $.123 *$ & 1 & & \\
\hline Continuance & -.015 & .092 & .012 & -.012 & $-.217 * *$ & .068 & .019 & $.176 * *$ & .021 & $.122 *$ & .076 & $.143 *$ & .021 & 1 & \\
\hline Normative & -.115 & .112 & -.002 & $-.107 * *$ & -.107 & $.110 *$ & -.072 & .120 & .209 & .109 & .121 & .132 & .043 & .021 & 1 \\
\hline POS & -.399 & .101 & -.112 & $-.033 * *$ & $-.058 * *$ & $-.111 * *$ & -.106 & -.012 & .039 & .104 & .105 & .054 & -.083 & .113 & .000 \\
\hline
\end{tabular}

${ }^{*} p<.05,{ }^{* *} p<.01$ 


\section{Results}

\subsection{Relationship between variables}

Table 3 summarizes the Pearson correlation test results between variables and reports the degree of multicollinearity between independent variables. The minimum tolerance of .729 , maximum variance inflation factor of 1.371 show that the statistical significance of the data analysis was not compromised by multi-collinearity.

\subsection{Hypothesis Test}

To analyze the relationships between organizational politics and social media addiction, the results in Table 4, consisting control and independent variables, show that organizational politics have statistical significances with subfactors of social media addiction. Moreover, it has positive relationships with mood modification $(\beta=.181, \mathrm{p}<.01)$, withdrawal $(\beta=.081, p<.01)$ and tolerance $(\beta=.024, p$ $<.01)$. However, it is shown to have no significance with preoccupation/salience and euphoria. This implies that the more narcissistic people are, the stronger their social media addiction are, which is expected in $\mathrm{H} 1$.

The results in Table 5 show the effects of sub-factors of social media addiction on the sub-factors of job satisfaction and organizational commitment. Salience has a negative effect on colleague satisfaction $(\beta=-.175, p<.01)$. Withdrawal has negative effects on colleague satisfaction $(\beta$ $=-.128, p<.05)$, supervision satisfaction $(\beta=-.179 p<.01)$ and affective commitment $(\beta=-.041, p<.01)$. Tolerance has negative effects on work satisfaction $(\beta=-.385, p<.01)$. This shows that the stronger social media addiction people have, the weaker their job satisfaction and organizational commitment are, which is expected in $\mathrm{H} 2$ and $\mathrm{H} 3$.

Table 4. Analysis 1

\begin{tabular}{|c|c|c|c|c|c|c|}
\hline \multirow{2}{*}{} & \multicolumn{7}{|c|}{ Social media addiction } \\
\cline { 2 - 8 } & Salience & conflict & $\begin{array}{c}\text { mood } \\
\text { modification }\end{array}$ & withdrawal & tolerance & relapse \\
\hline Sex & .037 & $.125 *$ & $-.077 *$ & $.036 *$ & -.061 & .073 \\
\hline Age & $.121 * *$ & -.049 & -.072 & -.068 & $.103 * *$ & $.032 * *$ \\
\hline Educational level & .013 & .041 & -.032 & .031 & -.044 & .022 \\
\hline Narcissism & -.041 & .119 & $.181 * *$ & $.081 * *$ & $.024 * *$ & -.109 \\
\hline Adj. $R 2$ & .008 & .013 & .114 & .109 & .154 & .009 \\
\hline$F$ & 1.569 & $2.115 *$ & $8.219 * *$ & $7.768 * *$ & $9.003 * *$ & 1.779 \\
\hline
\end{tabular}

${ }^{*} p<.05,{ }^{* *} p<.01$

Table 5. Analysis 2

\begin{tabular}{|c|c|c|c|c|c|c|c|c|}
\hline & \multicolumn{9}{|c|}{ Job satisfaction } & \multicolumn{3}{c|}{ Organizational commitment } \\
\cline { 2 - 10 } & Work & Pay & Promotion & Colleague & Supervision & Affective & Continuance & Normative \\
\hline Sex & $-.104 *$ & -.054 & .045 & -.009 & .035 & -.052 & .066 & .122 \\
\hline Age & $.178 * *$ & .059 & .043 & .051 & -.010 & $.108 * *$ & $.167 * *$ & .091 \\
\hline Educational level & .050 & .082 & -.032 & .074 & .022 & .032 & .026 & .052 \\
\hline Salience & -.054 & .059 & .068 & $-.175 * *$ & .018 & .022 & .012 & .022 \\
\hline Conflict & .012 & .068 & .059 & .024 & .048 & .011 & .043 & .036 \\
\hline $\begin{array}{c}\text { Mood } \\
\text { modification }\end{array}$ & .013 & -.053 & -.057 & -.050 & .094 & -.061 & -.051 & -.016 \\
\hline Withdrawal & -.058 & .054 & -.027 & -.128 & $-.179 * *$ & $-.041 * *$ & -.172 & .035 \\
\hline Tolerance & $-.385 * *$ & .012 & .026 & -.038 & -.017 & -.107 & .028 & .029 \\
\hline Relapse & .043 & -.022 & -.072 & -.102 & .051 & -.033 & -.021 & -.006 \\
\hline Adj. R2 & .191 & .007 & .008 & .068 & .018 & .081 & .031 & .009 \\
\hline$F$ & $9.945 * *$ & 1.274 & 1.347 & $3.786 * *$ & $1.883 *$ & $5.058 * *$ & $2.207 *$ & 1.514 \\
\hline
\end{tabular}

${ }^{*} p<.05,{ }^{* *} p<.01$ 
To test for mediating effects, the present study adopted the four steps of Baron and Kenny (1986). Baron and Kenny (1986) suggested four steps to establish mediation. Step 1 requires that the independent variable be significantly related to the dependent variable; step 2 requires that the independent variable be significantly related to the mediator; step 3 requires that the mediator affect the dependent variable while controlling for the effect of the independent variable. Finally, when these conditions are satisfied, step 4 requires that the effect of the independent variable on the dependent variable is insignificant when controlling for the mediator in order to indicate complete mediation; otherwise partial mediation is indicated. The mediating effect has the following relationship:

$$
\begin{aligned}
& Y=c X+e 1 \\
& M=a X+e 2 \\
& Y=c^{\prime} X+b M+e 3
\end{aligned}
$$

$\mathrm{Y}$ : dependent variable, $\mathrm{X}$ : independent variable, $M$ : mediating variable

Table 6 shows the analysis results. Model 1 is step 1 of Baron and Kenny (1986) and tests the relationship between narcissism and sub-factors of job satisfaction/organizational commitment that the sub-factors of social media addiction are positively associated with. Narcissism has negative effects on work satisfaction $(\beta=-.246, p<.01)$, colleague satisfaction $(\beta=-.206, p<.01)$ and supervision satisfaction $(\beta=-.382, p<.01)$ and also has negative effects affective commitment $(\beta=-.201, p<.01$. Step 2 of Baron and Kenny (1986) has already been shown in the results of Table 6 . In steps 3 and 4 of the mediation analysis, job satisfaction were regressed on organizational behavior, the sub-factors of social media addiction, and the control variables. Model 2 indicates the results, regarding job satisfaction and organizational commitment, the negative effect of narcissism on work satisfaction is weaker $(\beta=-.206, p<.01)$ when tolerance is entered into the equation $(\beta=-.131, p$ $<.05)$, which is partial mediation. The negative effect of narcissism on colleague satisfaction is weaker $(\beta=-.171, p$ $<.01)$ when withdrawal is entered into the equation $(\beta=-$ $.211, p<.05)$, which is partial mediation. The negative effect of narcissism on supervision satisfaction is weaker $(\beta=$ $.171, p<.05)$ when withdrawal is entered into the equation $(\beta=-.171, p<.01)$, which is partial mediation. Regarding organizational commitment, the negative effect of narcissism affective commitment is weaker $(\beta=-.201, p$ $<.05)$ when tolerance is entered into the equation $(\beta=-.111$, $p<.05)$, which is partial mediation. The negative effect of narcissism on affective commitment is weaker $(\beta=-.039, p$ $<.05)$ when withdrawal is entered into the equation $(\beta=-$ $.039, p<.01)$, which is partial mediation. These results are confirmed by the Sobel tests $(p<.05$ in all of significant cases). In the results, narcissism decrease job satisfaction and organizational commitment through social media

\begin{tabular}{|c|c|c|c|c|c|c|c|c|}
\hline & \multicolumn{6}{|c|}{ Job satisfaction } & \multirow{2}{*}{\multicolumn{2}{|c|}{$\begin{array}{c}\begin{array}{c}\text { Organizational } \\
\text { commitment }\end{array} \\
\text { Affective }\end{array}$}} \\
\hline & \multicolumn{2}{|c|}{ Work } & \multicolumn{2}{|c|}{ Colleague } & \multicolumn{2}{|c|}{ Supervision } & & \\
\hline & Model 1 & Model 2 & Model 1 & Model 2 & Model 1 & Model 2 & Model 1 & Model 2 \\
\hline Sex & $-.211 *$ & $-.208 *$ & -.032 & -.011 & .061 & .053 & -.081 & -.031 \\
\hline Age & $.161 * *$ & $.141 * *$ & .073 & .049 & -.039 & -.021 & $.128 * *$ & $.117 * *$ \\
\hline Education level & .092 & .074 & .051 & .031 & .043 & .027 & .091 & .041 \\
\hline Narcissism & $-.246 * *$ & $-.206 *$ & $-.206 * *$ & $-.171 * *$ & $-.382 * *$ & $-.321 *$ & $-.201 * *$ & $-.111 *$ \\
\hline Mood modification & & .008 & & -.052 & & .084 & & -.077 \\
\hline Withdrawal & & -.022 & & $-.211 *$ & & $-.171 * *$ & & $-.039 * *$ \\
\hline Tolerance & & $-.131 * *$ & & -.201 & & -.013 & & $-.117 *$ \\
\hline Adj. $R^{2}$ & .115 & .271 & .110 & .119 & .109 & .107 & .104 & .137 \\
\hline$F$ & $7.919 * *$ & $12.885 * *$ & $7.424 * *$ & $7.998 *$ & $7.601 * *$ & $7.393 *$ & $7.309 * *$ & $8.206 * *$ \\
\hline
\end{tabular}
addiction, which is expected in $\mathrm{H} 4$ and $\mathrm{H} 5$.

Table 6. Analysis 3

${ }^{*} p<.05,{ }^{* *} p<.01$ 
In Table 7, the results, consisting of moderators, shows the interactions between the narcissism and perceived organizational support. Perceived organizational support has a negative effect on the relationship $(\beta=-.121, p<.01)$ between narcissism and mood modification, the relationship $(\beta=-.133, p<.01)$ between narcissism and withdrawal, and the relationship $(\beta=-.102, p<.01)$ between narcissism and tolerance. Based on our results, when people have higher perceived organizational support in workplace, narcissism has weaker impact on their social media addiction, which is expected in $\mathrm{H} 6$.

Table 7. Analysis 4

\begin{tabular}{|c|c|c|c|}
\hline \multirow{2}{*}{} & \multicolumn{3}{|c|}{ SNS addiction } \\
\cline { 2 - 4 } & $\begin{array}{c}\text { Mood } \\
\text { modification }\end{array}$ & withdrawal & Tolerance \\
\hline Sex & -.032 & .039 & -.042 \\
\hline Age & -.002 & -.083 & $.102 * *$ \\
\hline Educational level & -.084 & .028 & -.018 \\
\hline Narcissism & $.111 *$ & $.108 *$ & $.131 * *$ \\
\hline $\begin{array}{c}\text { Perceived } \\
\text { organizational } \\
\text { support }\end{array}$ & $-.172 *$ & $-.122 * *$ & $-.015 *$ \\
\hline $\begin{array}{c}\text { Narcissism } \\
\text { Perceived } \\
\text { organizational } \\
\text { support }\end{array}$ & $-.121 * *$ & $-.133 *$ & $-.102 * *$ \\
\hline Adj. $R 2$ & .119 & .123 & .209 \\
\hline$F$ & $8.081 * *$ & $8.119 * *$ & $10.253 * *$ \\
\hline${ }^{*} p<.05,{ }^{* *} p<.01$ & & & \\
\hline
\end{tabular}

\section{Conclusion}

\subsection{Discussion}

Based on these empirical results, this study highlights some findings. First, narcissism increases mood modification, withdrawal, and tolerance among the subfactors of social media addiction. Second, each phenomena of social media addiction such as salience, withdrawal and tolerance decrease each relevant factors of job satisfaction and organizational commitment. However, conflict, mood modification, and relapse are not significantly related to job satisfaction and organizational commitment. And, all phenomena of social media addiction show no significance with both of pay and promotion satisfaction. Third, withdrawal and tolerance among the sub-factors of social media addiction play the mediating roles between narcissism and each relevant factors of job satisfaction/ organizational commitment. Finally, perceived organizational support decrease the effect of narcissism on mood modification, withdrawal and tolerance among the sub-factors of social media addiction.

This study makes three kinds of research implications. First, this study introduces social media addiction in the context of workplace and investigate organizational behaviors related to it. The study is the first to empirically verify the antecedents and consequences of social media addiction in the workplace. Second, this study shows the mediating effect of social media addiction between narcissism and organizational attitudes of employees. Third, this study suggests and empirically verifies that perceived organizational support is an interpersonal factor moderating the relationship between narcissism and social media addiction.

Moreover, this study provides some of practical and managerial implications to corporate executives who try to manage organizational attitude. Because social media addiction occurs in reality, it is also not ignorable in the context of workplace. Although the definition of social media addiction is inconsistent, social media may serve as a gratifying medium for people with high level of narcissistic traits particularly. It arouses social media addiction, which in turn decreases employees' job satisfaction and organizational commitment. Given this situation, corporate executives need to assign positions by considering individual factors.

\subsection{Limitations and future research directions}

The analysis results based on our interpretation of the questionnaires provided several insights into the relationships between organizational behaviors and social media addiction. However, I must also acknowledge the following limitations. First, this study collected our responses from employees who are working at Korean companies. This study can apply this study's methods to data samples in other countries in order to check the constancy of our variables' relationships. Second, as the variables were all measured at the same time, it cannot be sure that their relationships are constant. Although the survey questions occurred in reverse order of the analysis model to prevent additional issues, the existence of causal relationships between variables is a possibility. 


\section{References}

Aguinis, H. (2013). Performance Management (3rd ed.). Upper Saddle River, NJ: Prentice Hall/Pearson Education.

Agunis, H., \& Pierce, C. A. (2008). Enhancing the relevane of organizational behavior by embracing performance management research. Journal of Organizational Behavior, 29(1), 139-145.

Alarcón, R. D., \& Sarabia, S. (2012). Debates on the narcissism conundrum. Trait, domain, dimension, type or disorder. Journal of Nervous and Mental Disease, 200, 16-25.

Allen, N. J., \& Meyer, J. P. (1990). The measurement and antecedents of affective, continuance and normative commitment to the organization. Journal of Occupational Psychology, 63(1), 1-18.

Allen, K. A., Ryan, T., Gray, D. L., Mclnerney, D. M., \& Waters, L. (2014). Social media use and social connectedness in adolescents: The positives and the potential pitfalls. The Australian Educational and Developmental Psychologist, 31, 18-31.

American Psychiatric Association (1994). Diagnostic and Statistical Manual for Mental Disorders (4th ed.). Washington, DC: American Psychiatric Association.

Ames, D. R., Rose, P., \& Anderson, C. P. (2006). The NPI16 as a short measure of narcissism. Journal of Research in Personality, 40, 440-450

Andreassen, C. S. (2015). Online social network site addiction: A comprehensive review. Current Addiction Reports, 2, 175-184.

Andreassen, C. S., Pallesen, S., \& Griffith, M. D. (2017). The relationship between addictive use of social media narcissism, and self-esteem: Findings from a large national survey. Addictive Behavior, 64, 287-293.

Balaji, C. (1985). As organizational commitment decomposes: Issues in measuring multiple organizational commitments. Indian Journal of Industrial Relations, 28, 155-160.

Baron, R., \& Kenny, D. (1986). The Moderator-Mediator Variable Distinction in Social Psychological Research: Conceptual, Strategic and Statistical Considerations. Journal of Personality and Social Psychology, 51(6), 1173-1182.

Buffardi, L. E., \& Campbell, W. K. (2008). Narcissism and social networking web sites. Personality and Social Psychology Bulletin, 34, 1303-1314.

Cambell, W. K., Reeder, G. D., Sedikides, C., \& Elliot, A. (2000). Narcissism and comparative self-enhancement strategies. Journal of Research in Personality, 34, 329-347.
Chun, J., Joo, H., Jyung, C., Choi, W., \& Jeong, J. (2016). Job Satisfaction and Organizational Commitment of White Collars: Focus on Job Title. Journal of Distribution Science, 14(8), 23-33.

DeNisi, A. S., \& Pritchard, R. D. (2006). Performance appraisal, performance management and improving individual performance: A motivational framework. Management and Organization Review, 2(2), 253-277.

Echeburua, E., \& de Corral P. (2010). Addiction to new technologies and to online social networking in young people, a new challenge. Addictions, 22, 91-95.

Eisenberger, R., Huntington, R., Hutchinson, S., \& Sowa, D. (1986). Perceived organizational support. Journal of Applied Psychology, 71, 500-507.

Griffiths, M. D. (2005). A componets model of addiction within a biopsychosocial framework. Journal of Substance Use, 10, 191-197.

Griffiths, M. D., Kuss, D. J., \& Demetrovics, Z. (2014). Social networking addiction: An overview of preliminary findings. In K. P. Rosenberg and L. C. Feder (Eds.), Behavioral Addictions: Criteria, Evidence, and Treatment, (pp.119-41). London: Academic Press.

Grusky, O. (1996). Career mobility and organizational commitment. Administrative Science Quarterly, 10(4), 488-503.

Hall, D. T., Schneider, B., \& Nygren, H. T. (1970). Personal factors in organizational identification. Administrative Science Quarterly, 15(2), 176-190.

Jelinek, R., \& Ahearne, M. (2006). The enemy within: Examining salesperson deviance and its determinants. Journal of Personal Selling and Sales Management, 26(4), 327-344.

Judge, T. A., LePine, J. A., \& Rich, B. L. (2006). Loving yourself abundantly: Relationship of the narcissistic personality to self- and other perceptions of workplace deviance, leadership, and task and contextual performance. Journal of Applied Psychology, 91(4), 762-776.

Kim, S. W., Price, L., Mueller, C. W., \& Watson, T. W. (1996). The determinants of career intent among physicians at a U.S. Air Force hospital. Human Relations, 49(7), 947-976.

Kirschner, P. A., \& Karpinski, A. C. (2010). Facebook and academic performance. Computer Human Behavior, 26, 1237-1245.

Kuss, D. J., \& Griffiths, M. D. (2011). Online social networking and addiction: A literature review of empirical research. International Journal of Environmental and Public Health, 8, 3528-3552.

Kwon, J., \& Yang, H. (2015). Effects of Authentic Leadership and Leader-Member Exchange on Employee Psychological Ownership and 
Organizational Commitment. Journal of Distribution Science, 13(11), 23-30.

Luscombe, B. (2009). Social norms: Facebook and divorce. Time, 173, 93-94.

Maynard, D. C., Brondolo, E. M., Connelly, C. E., \& Sauer, C. E. (2015). I'm too good for this job: Narcissism's role in the experience of overqualification. Applied Psychology: An International Review, 64(1), 208-232

Mehdizadeh, S. (2010). Self-Presentation 2.0: Narcissism and Self-Esteem on Facebook. Cyberpsychology, Behavior, and Social Networking, 13(4), 357-364.

Muise, A., Christofides, E., \& Desmarais, S. (2009). More information than you ever wanted: Does facebook bring out the green-eyed monster of jealousy?. Cyber Psychology Behavior, 12, 441-444.

Nyland, R., Marvez, R., \& Beck, J. (2007). MySpace: Social networking or social isolation?. In Proceedings of the Midwinter Conference of the Association for Education in Journalism and Mass Communication, Midwinter Conference of the Association for Education in Journalism and Mass Communication, Reno, NV, USA 23-24 February 2007.

Park, K. H., Seong, N. C., \& Moon, J. S. (2016). The Effect of Distribution Enterprise Leader's Coaching Behavior on Organizational Citizenship Behavior and Turnover Intention: Mediating Role of Authentic Leadership and Moderating Role of Emotional. Journal of Distribution Science, 14(1), 75-84.

Persch, J. A. (2007). Jealous Much? MySpace, Facebook Can Spark It. New York, NY: The Msnbc Digital
Network. Retrieved August 18, 2011 from http://www.msnbc.msn.com/id/20431006/

Phillips, M. (2009). MySpace or Yours? Social Networking Sites Surveillance in Romantic Relationships. Mesa, AZ: Western States Communication Association.

Rhoades, L., \& Eisenberger, R. (2002). Perceived organizational support: A review of the literature. Journal of Applied Psychology, 87, 698-714.

Ryan, T., Chester, A., Reece, J., \& Xenos, S. (2014). The uses and abuses of Facebook: A review of Facebook addiction. Journal of Behavioral Addictions, 3, 133-148.

Smith, P. C., Kendall, L. M., \& Hulin, C. L. (1969). The measurement of satisfaction in work and retirement. Chicago: Rand McNally.

Tokunaga, R. S. (2011). Social networking site or social surveillance site? Understanding the use of interpersonal electronic surveillance in romantic relationships. Computer Human Behavior, 27, 705-713.

Twenge, J. M., \& Campbell, W. K. (2009). The Narcissism Epidemic: Living in the Age of Entitlement. New York, NY: Free Press.

Valkenburg, P. M., \& Peter, J. (2011). Online communication among adolescents: An integrated model of its attraction, opportunities, and risks. Journal of Adolescent Health, 48, 121-127.

Wallace, H. M., \& Baumeister, R. F. (2002). The performance of narcissists rises and falls with perceived opportunity of glory. Journal of Personality and Social Psychology, 82(5), 819-34. 